\title{
ONLINE GROCERY SHOPPING IS A PRIVILEGE OF MILLENNIAL CUSTOMERS. STILL TRUTH IN COVID-19 PANDEMIC?
}

\author{
[Nakupování potravin online jako výsada mileniálů. Je to stále pravda i v období \\ pandemie covidu-19?]
}

Radka Bauerová

\author{
${ }^{1}$ Silesian University, School of Business Administration, Univerzitní nám. 1934/3, 73340 Karviná \\ Email:bauerova@opf.slu.cz
}

\begin{abstract}
There has been a significant acceleration in the online grocery market due to the outbreak of the Covid-19 pandemic. This situational factor has accelerated the acceptance of grocery purchases in this way, but the question remains whether it also had an impact on the structure of customers buying grocery online. For a long time, online grocery shopping (OGS) has been the privilege of millennials, who like to shop online in all product categories. However, this paper also focuses on other generations and their development in consumer behaviour. The aim of the paper is to find out how Covid-19 influenced the proportion of selected generations of customers purchasing grocery online and whether it also affected their purchasing frequency. The findings from three surveys focused on online grocery purchases in the Czech Republic are used to find relevant results. Therefore, the research has the character of longitudinal research, but of tendency carried out on various respondents. Individual surveys were conducted in 2017, 2020 and June 2020 (after the outbreak of the Covid-19 pandemic). The results of the research can be useful for detecting changes in consumer behaviour and predicting the development of OGS within individual generations, usable for the strategic management of companies in this market.
\end{abstract}

Keywords: customer behaviour, customer profile, development of online grocery shopping, millennials, online grocery shopping.

JEL classification: M30, M31, M39

Received: 30.9.2020; Reviewed: 28.10.2020; 10.1.2021; Accepted: 19.5.2021

\section{Introduction}

The development of technology and the potential of using the internet has greatly influenced the way products are ordered, shipped and consumed today. More and more consumers have an internet connection, allowing more customers to make their purchases in the online environment. E-commerce significantly changed the way customers buy goods and services. The most frequently purchased products in the online environment today are electronics, home and garden equipment or fashion (Eurostat 2019). In these and many other categories, e-commerce penetration has grown at a very stable pace worldwide (Statista 2019). The only exception is the online grocery shopping, which in many countries is the least used way customers can buy their grocery. This theme is interesting for scientists in terms of differences in online and offline customer behaviour, causes and consequences. However, the topic is also interesting for practice because the proper customer relationship management and the correct setting of procedures and processes for online grocery sales are important in the relation of the increasingly popular way of online grocery purchasing around the world. For these reasons, this paper focuses on consumers' behaviour in online grocery shopping. The aim of the paper is to find out how Covid-19 influenced the proportion of selected generations of customers purchasing grocery online and whether it also affected their purchasing frequency. Research is focused on the development of individuals purchasing grocery online and their buying frequency, both from generation view. The literature review analyses the development and the current trend of online shopping, especially online grocery shopping worldwide with a focus on the Czech Republic as a place of primary research. The following part introduces the 
chosen research methods. The next part of the paper discusses the results provided. The last part of the paper concludes the major accomplishments of this research and describe interesting observations and future work.

\section{The current trend of online shopping}

The massive expansion of the internet and the acceleration of connections have impacted the daily life of consumers, which has made online shopping very easy for potential customers. The fact that the internet and technology have redefined the process of acquiring goods and services is confirmed by the growing popularity of online shopping. As early as 2016, online retailers' worldwide sales of $\$ 1.84$ trillion were forecasted to increase to $\$ 4.88$ trillion by 2021 (Statista 2019). Another interesting fact is that in 2018, almost 69\% of internet users in the European Union purchased products online (Eurostat 2019). If we focus on the Czech Republic, the development of online shopping has also dynamic growth. In 2003, only $13 \%$ of Czech customers purchased products online, while in 2018 it was 53.9\% of customers (CZSO 2019). This development shows that customers have quickly started using this new unconventional way of shopping, almost all over the world.

The need for innovation, the growth of e-tailers, or their expansion, is increasing with the growing number of online customers. This trend pushes companies to make strategic decisions in the case of distribution and communication policy. Therefore, the importance of creating valuable e-marketing, which aims to achieve established marketing goals through the application of digital technology is growing (Smith and Chaffey 2013). E-marketing is more than just the internet environment, as it incorporates additional technologies that enable customer relationship management, company resource planning, supply chain management, text messaging, barcode capture and digital television use (Gilmore et al. 2007). Brodie et al. (2007) state that e-marketing is becoming an important marketing practice in most companies and its success is based on the improvement and support of existing marketing practices.

The involvement of e-marketing among the marketing practices of Czech companies is important given the growing online sales in the Czech Republic. Internet purchases of individuals have been continuously increasing since 2007 in the Czech Republic. Based on the previous development of online products and economic situation in the Czech Republic, we can expect that the share of consumers buying online products will meanwhile continue to grow. In this context, the outcome of this paper can help identify different segments of consumers based on demographic and behavioural factors and reveal the impetus to buy grocery online. Managers can then effectively adjust their e-marketing tools to support online sales.

In 2015, the Czech Republic ranked fifteenth in the international comparison of the number of people purchasing products via the Internet in the European Union, in 2017 it was the thirteenth place (CZSO 2019). Interestingly, unlike the other countries surveyed, there are only $13.5 \%$ of retirees under the age of 74 who bought products online in the last 12 months (CZSO 2019). This may affect the location of the Czech Republic in the fifteenth and thirteenth places, compared to other European Union countries. For example, compared to the UK, the country with the highest number of individuals buying products over the Internet, there is a significant difference in the proportion of shoppers in that customer segment. The number of retirees who buy online is more than four times higher in the UK than the Czech Republic. However, if we look at a detailed analysis, we find that the number of online retirees has increased nine times between 2006 and 2018 (CZSO 2019). The internet knowledge and skills of older people, who already belong to the 64-74 age category, continue 
to grow. In this segment, there is also a gradual addition of people from the previous category who have higher technological literacy (CZSO 2015). This trend can cause a significant increase in online shoppers in this customer category in the future.

\subsection{Specifics of online grocery shopping}

Depending on individual purchases' development in the online environment, online grocery shopping is one of the most dynamically developing online category (Eurostat 2020, Statista 2020a). The Nielsen research company found, on a sample of 60 countries surveyed, that onequarter of respondents claim to order grocery online and more than half $(55 \%)$ of respondents are willing to buy grocery online in the future (The New Retail Report 2015). Moreover, Nielsen research company predict, it is likely that by 2024 , up to $70 \%$ of customers will be buying grocery online (Nielsen 2020). The largest proportion of online grocery buyers in 2019 was found in Netherlands (45\%) the United Kingdom (35\%), Germany (30\%) and Estonia (34\%), Lithuania (33\%). Even the Czech Republic, with 39\%, has a relatively high proportion of online grocery buyers compared to the rest of Europe (Eurostat 2020).

Although online grocery shopping has already been perceived as a dynamic category of the online market in recent years, the researches show (CNBC 2020, Statista 2020b) that current market situation affected by the Covid-19 has further intensified and accelerated this trend. The research found this situation influenced older households as well in their perception and willingness to buy (Beck and Hesher 2020). Overall, more customers used buying groceries offline moved to online shopping due to Covid-19 very rapidly (Charlebois 2020, Li et al. 2020).

Online grocery shopping is now at the forefront of companies and researchers. Understanding the motivation and constraints of customers when shopping for groceries online is essential to businesses. There are two types of retailers offering online grocery service. Those that trade only online is called e-tail organizations. Traditional business companies using the offline and online environment are called hybrid organizations. In the case of hybrid retailers, it is important to effectively manage all sales channels (e.g. websites, traditional stone shops, call centre) to make consumers satisfied. Above all, Y customers prefer an online source of information to traditional media (Klapilová 2016). Therefore, multi-channel customer management is emerging strategic decision-making for hybrid retailers. Effective design, deployment and evaluation of communication channels are perceived as a key marketing decision to increase customer value through their effective acquisition and development (Neslin et al. 2006).

Researchers are particularly interested in the behaviour of online grocery shoppers. For example, it has been found that online brand selection is almost identical to traditional customer behaviour (Anesbury et al. 2016). However, online grocery stores usually sell local fresh and tasty grocery, which positively affects customers who want to support their local produce and community (Miškolci 2017). Of course, differences in shopping behaviour between online and traditional shopping environments are caused by the interface and capabilities of online technologies. For example, the web interface has significantly reduced the time it takes to purchasing (Anesbury et al. 2016).

Customer behaviour has gradually changed as a result of the continuous development of online grocery purchases, in response to the unique opportunities and challenges of the online environment, as reflected in the composition of the shopping basket. For example, online customers are surprisingly spending more money on fresh products than offline customers, 
which is contrary to popular prejudices that customers are afraid to buy fresh products online (Munson et al. 2017).

Given the knowledge discussed above, it can be concluded that online grocery shopping is an up-coming trend worldwide. Several research studies on online grocery purchases have started to grow gradually along with the rapid growth rate of grocery online buyers. These studies focused on consumer behaviour (Anesbury 2016), the impact of shopping frequency on perceived risk (Mortimer et al. 2016), the impact of online shopping by purchasing healthier foods (Huyghe et al. 2016), factors affecting customer satisfaction loyalty or buying behaviour (Lim et al. 2016), or exploring the overall acceptance of online shopping (Bauerová and Klepek 2018).

\subsection{Factors influencing the behaviour of online grocery buyers}

Customers prefer to shop online for products and services that pose little risk to purchase, but there is still a prevailing view that customers prefer physical retail to retail in the online environment (Lee and Tan 2003). An important determinant of online shopping is the product categories and characteristics themselves. Jain and Jain (2011) divide products into a range from the ones that sell most on the Internet to those that are least popular on the Internet, including grocery. The reason is that people are more willing to buy cheap and intangible products online, and are less willing to buy products whose frequency of shopping is frequent (Lee and Tan 2003, Jain and Jain 2011, Maat and Konings 2018). Customers generally buy based on functional, physical or economic needs, but there are other more specific and more individual shopping motives when shopping grocery online. For example, factors such as time savings and distance to a supermarket are more influential than the cost of order delivery (Huang and Oppewal 2006).

In contrast to offline shopping, it takes customers only a few seconds to select and choose their product online (Anesbury et al. 2016), regular customers can make their entire purchase using redefined shopping lists in minutes (Robinson et al. 2007) and perceived lack of time to purchase thus, in the life of customers, it is one of the important factors for buying grocery online. Perceived time savings relate to the time of purchase at the store itself and also saves time to avoid a difficult traffic situation and not waste time searching for a parking space. Other factors include those based on the theory of technological acceptance. In the grocery theme, it has been confirmed that the perceived usefulness and perceived ease of use factors of the mentioned model have an impact on the intention to use online grocery shopping (Bauerová and Klepek 2018, Driediger and Bhatiasevi 2019). Moreover, Driediger and Bhatiasevi (2019) found that subjective norms and enjoyment also act on customers according to the model. They defined subjective norm as feelings that influential people of customer' environment think that online grocery shopping is a good thing to do. In the case of enjoyment, they stat that it means that user perceives online grocery shopping to be enjoyable. However, instead of subjective norms, some authors use social influence as a factor that can affect consumers (Pauzi et al. 2017). Consumers under this factor can change their mind and become online grocery buyers.

In addition to the aforementioned factors, some others may affect customers' shopping intent in the online environment, such as situational factors. These factors are characterized by the fact that, when a situation arises, consumers start to buy grocery online. It was found that situational factors, such as having a baby or developing health problems, are triggers for starting to buy groceries online (Harris et al. 2009). The current most visible situational factor is the outbreak of the Covid-19 pandemic, which has affected all consumers in the world in 
some way. The latest studies shows the coronavirus pandemic has a positive influence on the percentage of groceries being bought online by consumers (Dannenberg et al. 2020, MartinNeuninger \& Ruby 2020). This change can be caused by perceived online grocery shopping as a good way to minimize the spread of the virus (Martin-Neuninger \& Ruby 2020). These changes are rather positive in the field of online grocery shopping. However, it has also been found that this situational factor causes stock panic behavior not only offline but also when shopping grocery online (Hao et al. 2020, Islam et al. 2021) and companies have problems solving logistics, changing established business models (Dannenberg et al. 2020). Despite these negative effects caused by the situational factor, many retail stores are expanding their online capabilities to cope with the increased demand in the online grocery market (MartinNeuninger \& Ruby 2020).

The last group of factors we will mention are demographic factors. It was found that higherincome households are more inclined to buy groceries online (Maat and Konings 2018). They stated that this finding is important due to the situation that home delivery for groceries comes with a delivery fee, to which higher-income households are less sensitive. Another demographic factor examining in online grocery shopping perspective is age, which Bauerová and Klepek (2018) analysed in online grocery field from the generations' perspective. They found differences between customers' generations when analysed shopping motives and attitudes towards digitization of grocery. Next study divided online grocery customers into five groups based on personal characteristics as working mothers, young professionals, SilverSurfers, others and groups combined (Seitz et al. 2017). They also found differences between motives to shop grocery online and research groups. Meanwhile working mothers and young professionals strongly benefit from timesaving, SilverSurfers benefit from the service that reduces their heavy physical work. These results correspond with the results of customers' generation perspective study (Bauerová and Klepek 2018). Other authors also focus on the generations of online grocery shopping, but among these studies, a view of Generation Y (Rahman 2015, Saleem et al. 2018, Kumar and Sadarangani 2018), which is perceived as the most numerous and valuable, prevails. Studies examining intergenerational differences suggest that there are generational differences between the perception of online grocery shopping and the intention to buy grocery online (Mansori et al. 2012), generational differences between gender role (Van Droogenbroeck and Van Hove 2020). Kuhns and Saksena (2017) found that Generation Y exhibit a higher preference for convenience than do other generational cohorts when making online grocery purchases, with the largest budget shares going to grocery categories dominated by ready-to-eat foods.

It can be said many factors affect customers when buying grocery online and it would be very difficult to examine them all at once. Therefore, this research focuses only on the situational factor associated with Covid-19, which is now a little studied in this field in terms of the generational differences (from the perspective of the three most important generations currently in connection with online grocery shopping). The research could thus provide insights into whether this situational factor has influenced the customer shopping frequency given selected generations. Research answer the question of whether there was a faster acceptance of online shopping by customers across selected generations' categories, or whether this factor only affected millennials, who are already characterized by a very positive perception of this way of grocery shopping.

\section{Methods}

The research in this paper has an element of continuous research due to using three primary surveys. To achieve the formulated aim the secondary data from the Eurostat database were 
used as well. The development of customer behaviour within generations and their frequency of shopping grocery online was determined by combining the results of secondary and primary research. First was identified, there are available the secondary data about individuals purchasing grocery online within age categories. To find out how Covid-19 influenced the current situation from generation view and to examine the frequency of purchasing grocery online within these generations, the primary data were needed. Therefore, the research in June 2020 was realized. The previous surveys from 2017 and 2020 were also used to find differences in purchasing frequency from a generation perspective.

\subsection{Research design}

Three surveys were conducted to examine the development of online grocery behavior from a generation perspective. The first survey was conducted in 2017 and together with the survey from January 2020 was realized through IPSOS respondent panel. This panel included customers purchasing grocery online. The first research obtains 1050 respondents. A total of 173 respondents were excluded from research due to cleaning data process. Most of them were excluded due to the revelation that they did not buy grocery online (by an open question) as a part of logical control. The rest of them were excluded due to analyzing the standard deviation. The second survey obtains 939 respondents. After cleaning data process 146 respondents were excluded from following testing based on logical control and standard deviation. The last research was realized by self-collection through online discussions and forums focused on online grocery shopping and grocery shopping in connection with the consequences of the Covid-19. The combined students were also contacted via the university's e-mail to obtain a larger number of respondents. Students could answer the questionnaire only if they had ever bought grocery online. This research contained 234 respondents. Based on the same cleaning data process as previous surveys, 39 respondents were excluded.

To determine the dependencies between the generation to which customers belong and the frequency of buying grocery online, the K-S test was first used to determine the normal distribution of data. After evaluating the K-S test, the Kruskal-Wallis H test was performed, as the condition for its use was met (data do not have a normal distribution). Subsequently, an analysis of frequencies was applied in the analysis of ordinal data to find differences in the frequency of online grocery shopping within individual customers' generations. This method was chosen because the purpose was to detect possible changes in the structure of customers buying grocery online caused by the Covid-19 pandemic. Based on the results, it was possible to decide whether the investigated situational factor had an effect on the acceleration of OGS. The IBM SPSS software was used to cleaning and processing the primary data.

\subsection{Data characteristics}

The following table shows the characteristics of the final research samples from all of the used primary researches. Only generations X, Y and Baby Boomers were selected in the research. It was necessary to count with different years of collected responses for correct classification to individual generations. Within the theory of generations (Hole et al., 2012), respondents from the 2017 research fall into individual generations as follows: Baby Boomers (more than 51 years), Generation X (37 - 51 years) and Generation Y (17 - 36 years). Two surveys carried out in 2020 has the same distribution of generations as follows: Baby Boomers (more than 54 years), Generation X (40 - 54 years) and Generation Y (20 - 39 years).

The research also included respondents belonging to generation $\mathrm{Z}$, but these respondents were so few in the surveys that they were not included in the research to maintain the relevance of 
the results. Specifically, 5 respondents from the 2017 survey, 20 respondents from the January 2020 survey and 3 respondents from June 2020 belonging to the $\mathrm{Z}$ generation were excluded from the research. In all three surveys, the largest share of the Y generation and the smallest share of the Baby Boomers generation are evident. This also corresponds to the secondary research, which shows the development of individuals in these generations over the last five years (Tab. 2).

Table 1: Research sample characteristics (primary data)

\begin{tabular}{|c|l|c|c|c|c|c|c|}
\hline \multirow{2}{*}{ Variable } & \multirow{2}{*}{ Statistics properties } & \multicolumn{2}{c|}{$\begin{array}{c}\text { December 2017, } \\
\mathbf{n = 8 7 7}\end{array}$} & \multicolumn{2}{c|}{$\begin{array}{c}\text { January 2020, } \\
\mathbf{n = 7 7 3}\end{array}$} & \multicolumn{2}{c|}{$\begin{array}{c}\text { June 2020, } \\
\mathbf{n}=\mathbf{1 9 5}\end{array}$} \\
\cline { 3 - 8 } & & $\mathbf{C o u n t}$ & $\mathbf{\%}$ & Count & $\mathbf{\%}$ & Count & \% \\
\hline \multirow{2}{*}{ Gender } & Man & 427 & 48,6 & 373 & 48,3 & 82 & 41,6 \\
\cline { 2 - 8 } & Woman & 450 & 51,3 & 400 & 51,7 & 113 & 57,4 \\
\hline \multirow{3}{*}{$\begin{array}{c}\text { Generations } \\
\end{array}$} & Baby Boomers & 238 & 27,1 & 153 & 19,8 & 16 & 8,2 \\
\cline { 2 - 8 } & Generation X & 294 & 33,5 & 243 & 31,4 & 63 & 32,3 \\
\cline { 2 - 8 } & Generation Y & 345 & 39,3 & 357 & 46,2 & 113 & 57,9 \\
\hline \multirow{2}{*}{$\begin{array}{c}\text { Online } \\
\text { grocery } \\
\text { shopping }\end{array}$} & Several times a month & 115 & 13,1 & 153 & 19,8 & 61 & 31,3 \\
\cline { 2 - 8 } & Several times a quarter & 145 & 16,5 & 153 & 19,8 & 51 & 26,2 \\
\cline { 2 - 8 } & Several times a year & 199 & 22,7 & 170 & 22,0 & 31 & 15,9 \\
\cline { 2 - 8 } & Less often & 418 & 47,6 & 297 & 38,4 & 52 & 26,6 \\
\hline
\end{tabular}

Source: own research

Looking at the frequency of online grocery shopping in general, the increasing frequency of purchases per month over time is evident. The highest change in purchasing frequency was recorded between the January 2020 and June 2020 surveys. This change was even higher than the change from 2017 survey to January 2020 survey. At the same time, the percentage of individuals shopping grocery online irregularly has been declining since 2017.

\section{Results}

This part of the paper presents research results based on which it is possible to answer a formulated research question. The research question was whether there was a faster acceptance of online shopping by customers across all age categories, or whether this factor only affected millennials, who are already characterized by a very positive perception of this way of grocery shopping. To answer this question, the development of customers purchasing grocery online within selected generations was first analysed.

Since the secondary data showed only this development within the age categories, only those age categories that fit their range to a specific generation of customers were examined. Secondary data were also available only until 2019. Newer data have not yet been published by Eurostat. For this reason, the findings of the primary research from June 2020 was added to these dates. In this research, it was found that $38.05 \%$ of customers purchasing grocery online from Generation Y started to use this service only based on the situational factor (Covid-19). Given this finding, it was calculated by analogy based on previous data from secondary research that the estimated possible increase in customers shopping grocery online in this generation is $15.22 \%$. This procedure was also applicated in the case for Generation $\mathrm{X}$ $(+7.82 \%)$ and Baby Boomers $(8.75 \%)$ customers.

In all cases, these estimated increases exceeded the average increments over the period under review in the individual customers' generation categories. However, only in the case of Generation Y and Generation Baby Boomers, based on the trend over the last 5 years, it was found that Covid-19 made a significant contribution to the acceptance of online shopping. Within Generation X, there was also an increase in the number of individuals, but this change 
was not the largest in the period under review, so it cannot be said that the investigated situation factor accelerated the acceptance of this way of obtaining grocery by this generation. The combined outputs from the secondary and primary research are shown in Table 2.

Table 2: Development of individuals purchasing grocery online in selected generations (in percentage)

\begin{tabular}{|l|c|c|c|c|c|c|c|c|}
\hline \multirow{2}{*}{$\begin{array}{l}\text { Approximate } \\
\text { generation }\end{array}$} & Age & \multicolumn{6}{|c|}{ Secondary research } & \multicolumn{2}{c|}{ Primary Research } \\
\cline { 3 - 9 } & & $\mathbf{2 0 1 5}$ & $\mathbf{2 0 1 6}$ & $\mathbf{2 0 1 7}$ & $\mathbf{2 0 1 8}$ & $\mathbf{2 0 1 9}$ & $\begin{array}{l}\text { App. } \\
\text { Gen. }\end{array}$ & $\mathbf{2 0 2 0}$ estimates \\
\hline Generation Z and Y & $16-24$ & 1 & 6 & 12 & 23 & 29 & $/$ & $/$ \\
\hline Generation Y & $25-34$ & 5 & 15 & 20 & 30 & 40 & Y & $+38,05 \% * \rightarrow 55,22$ \\
\hline Generation Y and X & $35-44$ & 4 & 11 & 19 & 26 & 35 & $/$ & $/$ \\
\hline Generation X & $45-54$ & 3 & 9 & 11 & 24 & 29 & $X$ & $+26,98 \%^{*} \rightarrow 36.82$ \\
\hline Baby Boomers & $55-74$ & 2 & 5 & 7 & 12 & 14 & BB & $+62,50 \% * \rightarrow 22,75$ \\
\hline
\end{tabular}

*percentage of respondents who started to buy grocery online due to Covid-19 in selected generations

Source: Eurostat database 2020; own data from June 2020 survey; own illustration

The next step in examining the acceptance of online grocery shopping in individual generations was to focus on the frequency of these purchases. In the first phase of the research, it was found that due to the effect of the situational factor, there was a faster acceptance within Generations Y and Baby Boomers. However, the question remained whether the situation factor had an effect on the frequency of purchases, which may indicate the strength of this acceptance. The data are therefore further analysed in terms of the impact of the generation to which customers belong on the frequency of online grocery shopping over time $(2017,2020$, June 2020).

The data were first checked to find if they had a normal distribution. The K-S test was used to prove this. The analysis showed that the data for all investigated periods do not have a normal distribution and therefore it is possible to use the Kruskal-Wallis $\mathrm{H}$ test for further analysis. The results of the Kruskal-Wallis H test (Table 3) show that in 2017 (sig. $=0.012 ;<0.05$ ) and 2020 (sig. $=0.030 ;<0.05$ ) the frequency of online grocery purchases depends on the generation to which customers belong, while in June 2020 this dependence was not confirmed (sig. $=0.522 ;>0.05)$.

Table 3: The results of the Kurskal-Wallis H tests

\begin{tabular}{|l|r|r|r|}
\hline \multirow{2}{*}{ Kruskal-Wallis H test } & \multicolumn{3}{|c|}{ Time period } \\
\cline { 2 - 4 } & $\mathbf{2 0 1 7}$ & January 2020 & June 2020 \\
\hline Chi-Square & 8.929 & 7.000 & 1.302 \\
\hline Df & 2 & 2 & 2 \\
\hline Sig. & 0.012 & 0.030 & 0.522 \\
\hline
\end{tabular}

Source: own research

The results of proven analysis show that the situational factor (covid-19 pandemic) had an effect on the change in consumer behaviour within the frequency of online grocery purchases and caused a reduction in generational differences.

Figure 1 presents the results of the second part (phase) of the research in terms of percentage frequency. Individual generations of customers were examined for changes in the frequency of online grocery purchases over time (2017, January 2020, June 2020). Although in the previous phase it was confirmed that situational factor affected the faster acceptance of online grocery shopping in only two of the three generations examined, in this phase, it was revealed that the strength of acceptance (expressed by frequency of purchases) was positively influenced by all studied customers' generations. 
Figure 1: The frequency of online grocery shopping within individual customers' generations

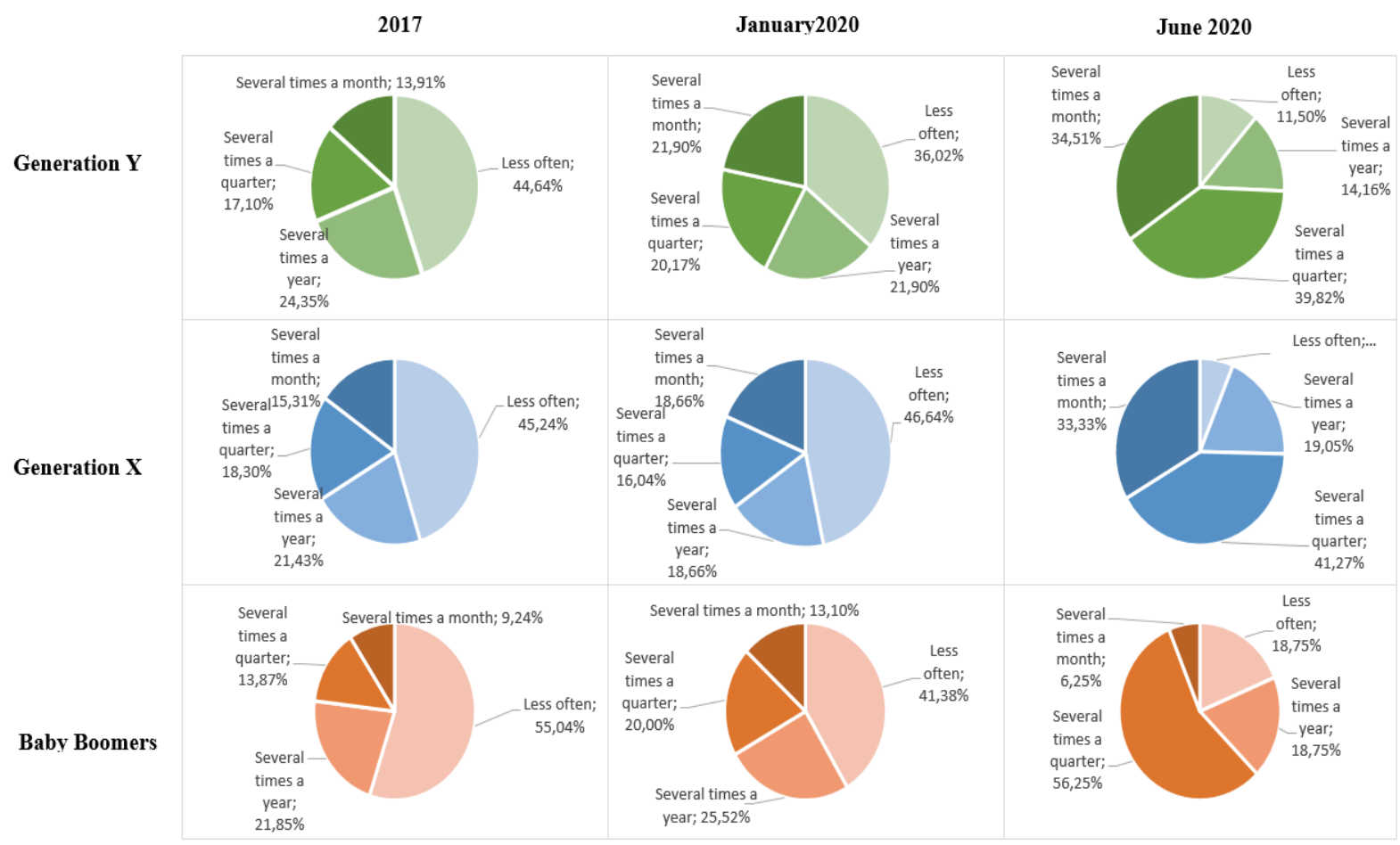

Source: own research

When examining the ratio of the frequency of grocery purchases between the 2017 and January 2020 surveys, the change is not significantly recorded. It is evident that this frequency increased slightly in all categories examined, but when compared to the June 2020 survey, this increase is not so significant. It is therefore clear that the situation factor also had a significant effect on the ratio of the online grocery shopping frequency in all generations examined. The most significant changes are presented in the following paragraphs for each generation separately.

Within Generation Y, the most significant change occurred when shopping for grocery online in the "less often" category. Overall, 24.5\% fewer customers feel identified with this purchasing frequency. Another significant change was recorded in the "several times a quarter" category. This way almost $20 \%$ more customers purchasing grocery online in just six months.

Generation $\mathbf{X}$ significantly increased its purchasing frequency in the monitored period of January 2020 / June 2020. Overall, 40.29\% of customers from this generation increased their purchasing frequency. Most of them started purchasing grocery online several times and a quarter.

Customers from the Baby Boomers generation have also changed their behaviour within the online grocery shopping frequency. A total of $36.25 \%$ started purchasing several times a quarter. However, there was also a slight decrease in this group of those who bought grocery several times a month. In this group, as the only one, the frequency decreased for almost $7 \%$ of customers, but at the same time for $65.65 \%$ the frequency of purchases increased. It can therefore be argued that the situation factor also had a positive effect on increasing the frequency of online grocery purchases for this group of customers. 
This part of the research shows that the Generation to which the customer belongs has an effect on the frequency of food purchases in 2017 and early 2020. In June 2020, the generation to which the customer belongs has no effect on the frequency of purchase. From this finding, it is clear that the situational factor (covid-19) had a significant effect on consumer behaviour from an generational perspective, and its effects accelerated the acceptance of online grocery shopping.

\section{Discussion}

Based on the research results, it can be argued that due to the influence of the situation factor (Covid-19), the acceptance of online grocery purchases has accelerated not only in the millennial generation but also in the Baby Boomers generation. Within Generation X, there has been found an increase in customers, but this increase does not deviate significantly from the established trend in this generation. The biggest acceleration was recorded within the Baby Boomers generation, which had the slowest acceptance of online grocery shopping in the last five years. This acceleration may be caused to the fact this generation is a high-risk segment of consumers within the impact of the examined situational factor (Covid-19). In terms of the purchasing frequency within examined generations, it was found that the change in the ratio between study frequencies was negligible when comparing the results of research from 2017 and January 2020. However, the ratio has changed significantly compared to the latest survey from June 2020, where it is evident that the frequency of shopping grocery online has increased across all examined generations. The most significant change was again recorded in the case of Baby Boomers.

To answer the research question, it can be said that there was a faster acceptance of online grocery shopping by customers across almost all age surveyed categories (millennials and Baby Boomers), therefore the examined situational factor not affected only millennials. This finding points to ongoing changes in the structure of customers purchasing grocery online. These changes can affect consumer behaviour in the industry, as generations differ in their views on the benefits of shopping for grocery online or in their shopping motives (Bauerová and Klepek 2018). The research results confirm the previous studies suggest that Covid-19 influenced older households in online grocery purchases (Beck and Hesher 2020) and that Covid-19 very rapidly change the ratio of customers shopping grocery online (Charlebois 2020, Li et al. 2020).

The biggest limit of this research may be the different numbers of respondents in individual surveys. The same group of respondents was not examined in the research. This could have skewed the research result since the same sample of respondents was not maintained throughout the whole research. The author of this paper tried to reduce this bias by setting criteria for respondents selected for this long-term research. All respondents thus meet the condition of experience with purchasing grocery online and reaching the minimum age of 18 , which is required for the purchase of the entire range of goods that online or hybrid (operating both online and offline) grocery retailers offer.

\section{Conclusion}

The results suggest that the Covid-19 pandemic has affected both the structure of customers in the online grocery market and the frequency of their purchases across generations. Online grocery shopping is still a privilege of millennial customers (Generation Y). However, research suggests that acceptance of this way of shopping is also increasing among other generations of customers, and even significantly faster among Baby Boomers than among 
millennials. Furthermore, it can be said that the investigated situational factor accelerated the acceptance of online grocery shopping and at the same time the frequency of these purchases.

This knowledge is valuable for marketing strategy managers, as in the context of online grocery purchases, due to found changes, they should also target new customers from all examined groups of generations. The current typical customer of this service is women on maternity leave (Kladivová 2019). However, in the nearly future there is a possibility to switch this trend and mitigating the frequency purchasing differences between generations. Based on results, there is a chance that Baby Boomers (or some segment of this group) may be the future not literally typical, but very countable customer group. This would have been an unlikely scenario a year ago, but given the changes in the number of individuals purchasing grocery online in this customer group and the change in their purchasing frequency due to the Covid-19 pandemic, this option needs to be included in the strategic challenges of retailers operating in this market. For the strategic management of retailing companies, the estimation of trends in consumer demand is an important factor for the correct prediction of sales and management of retail processes. The observed changes in the distribution of generations and the frequency of their shopping within the online grocery are certainly one of these important trends that must be taken into account.

\section{Acknowledgement}

This research was financially supported by the student grant competition project SGS/20202021: "Business Strategies of Online Trade Organizations and Customers".

\section{References}

[1] ANESBURY, Z., M. NENYCZ-THIEL, J. DAWES and R. KENNEDY, 2016. How do shoppers behave online? An observational study of online grocery shopping. Journal of Consumer Behaviour, 3(15), 261-270. ISSN 14720817.

[2] BAUEROVÁ, R. and M. KLEPEK, 2018. The Digitalization of a Grocery Shopping from a Generation Perspective. In: L. CABYOVA, R. RYBANSKY and $\mathrm{Z}$. BEZAKOVA, eds. Proceedings of the Annual International Scientific Conference Marketing Identity 2018: Digital Mirrors, Trnava: University of Ss. Cyril and Methodius, 243-255. ISBN 978-80-8105-985-8.

[3] BAUEROVÁ, R. and M. KLEPEK, 2018. Technology acceptance as a determinant of online grocery shopping adoption. Acta Universitatis Agriculturae et Silviculturae Mendelianae Brunensis, 66(3), 737-746. ISSN 1211-8516.

[4] BAUEROVÁ, R. and M. KLEPEK, 2018. The Digitalization of a Grocery Shopping from a Generation Perspective. In: Cabyova, L., Rybansky, R., Bezakova, Z., eds. Proceedings of International Scientific Conference: Marketing Identity: Digital Mirrors, Trnava: Pt I. Univ Ss Cyril \& Methodius Trnava-Ucm Trnava, 243-255. ISSN 13395726.

[5] BECK, M. J. and D. A. HENSHER, 2020. Insights into the Impact of Covid-19 on Household Travel, Working, Activities and Shopping in Australia - the early days under Restrictions. ITLS Working paper No.10. [online]. [cit. 27th September 2020]. Available from: https://ses.library.usyd.edu.au/handle/2123/22247

[6] BRODIE, R. J., H. WINKLHOFER, N. E. COVIELLO and W. J. JOHNSTON, 2007. Is E-Marketing Coming of Age? An Examination of the Penetration of E-Marketing and Firm Performance. Journal of Interactive Marketing, 21(1), 2-21. ISSN 1094-9968. 
[7] CHAFFEY D. and P. R. SMITH, 2013. EMarketing eXcellence: planning and optimizing your digital marketing. 4th Ed. London: Routlege. ISBN 978-0415533379.

[8] CHARLEBOIS, S., 2020. Why COVID-19 will change Canadian grocery industry forever: Expert. Retail Insider. [online]. [cit. 25th September 2020]. Available from: https://www.retail-insider.com

[9] CNBC, 2020. Retail. [online]. [cit. 26th September 2020]. Available from: https://www.cnbc.com/2020/05/01/as-coronavirus-pushes-more-grocery-shoppersonline-stores-struggle-with-demand.html

[10] CZSO Information leaflet, 2015. Information technologies in houselohlds and between individuals [online]. [cit. 22nd September 2020]. Available from: https://www.czso.cz/documents/10180/23180875/letak_jednotlivci.pdf/f499cc8b-82154 fac-a33c-b1fc067dccd2?version=1.1

[11] CZSO Information Society in Figures Report, 2019 [online] [cit. 22nd September 2020]. Available from: https://www.czso.cz/csu/czso/information_society_in_figures

[12] DANNENBERG, P., M. FUCHS, T. RIEDLER and C. WIEDEMANN, 2020. Digital Transition by COVID-19 Pandemic? The German Food Online Retail. Tijdschrift Voor Economische En Sociale Geografie, 111(3), 543-560. ISSN 1467-9663.

[13] DRIEDIGER, F. and V. BHATIASEVI, 2019. Online grocery shopping in Thailand: Consumer acceptance and usage behavior. Journal of Retailing and Consumer Services, 48(1), 224-237. ISSN 0969-6989.

[14] EUROSTAT Internet purchases by individuals, 2020. [online] [cit. 26th August 2020]. Available from: http://appsso.eurostat.ec.europa.eu/nui/submitViewTableAction.do

[15] GILMORE A., D. GALLAGHER and S. HENRY, 2007. E-marketing and SMEs: Operational Lessons for the Future. European Business Review, 19(3), 234-247. ISSN 0955-534X.

[16] HAND, CH., F. D. RILEY, P. HARRIS, J. SINGH and R. RETTIE, 2009. Online grocery shopping: the influence of situational factors. European Journal of Marketing, 43(9), 1205-1219. ISSN 0309-0566.

[17] HAO, N., H. H. WANG and Q. ZHOU, 2020. The impact of online grocery shopping on stockpile behavior in Covid-19. China Agricultural Economic Review, 12(3), 459-470. ISSN 1756-137X.

[18] HOLE, D., L. ZHONG and J. SCHWARTZ, 2010. Talking About Whose Generation? Why Western generational models can't account for a global workforce. Birmingham: Deloitte Development LLC.

[19] HUANG, Y. and H. OPPEWAL, 2006. Why consumers hesitate to shop online: An experimental choice analysis of grocery shopping and the role of delivery fees. International Journal of Retail \& Distribution Management, 34(4), 334-353. ISSN 09590552 .

[20] HUYGHE, E., J. VERSTRAETTEN, M. GEUENS and A. V. KERCKHOVE, 2016. Clicks as a Healthy Alternative to Bricks: How Online Grocery Shopping Reduces Vice Purchases. Journal of Marketing Research, 54(1), 61-74. ISSN 0022-2437.

[21] ISLAM, T., A. H. PITAFI, V. ARYA, Y. WANG, N. AKHTAR, S. MUBARIK and L. XIAOBEI, 2021. Panic buying in the COVID-19 pandemic: A multi-country examination. Journal of Retailing and Consumer Services, 59, 102357. ISSN 0969-6989. 
[22] JAIN, S. J. and M. JAIN, 2011. Exploring Impact of Consumer and Product Characteristics on E-Commerce Adoption: A Study of Consumers in India. Journal of Technology Management for Growing Economies, 2(2), 35-64. ISSN 2456-3226.

[23] KLADIVOVÁ, B., 2019. iRozhlas. Každý sedmý Čech nakupuje jídlo přes internet. Eshopům však chybi capacity, zkouši proto inovace. [online]. [cit. 22nd September 2020]. Available form: https://www.irozhlas.cz/ekonomika/nakup-potravin-online-eshopy_1905111130_jak

[24] KLAPILOVÁ KRBOVÁ, P., 2016. Shopping Behaviour of Generation Y: A Comparison of Czech Republic and Slovakia. Acta Universitatis Agriculturae et Silviculturae Mendelianae Brunensis, 64(2), 617-626. ISSN 1211-8516.

[25] KUMAR, S. and P. SADARANGANI, 2018. An Empirical Study on Shopping Motivation among Generation Y Indian. Global Business Review, 1. ISSN 0972-1509.

[26] LEE, K. S. and S. J. TAN, 2003. E-Retailing Versus Physical Retailing: A Theoretical Model and Empirical Test of Consumer Choice. Journal of business research, 56(11), 877-885. ISSN 0148-2963.

[27] LI, J., A. G. HALLSWORTH and J. A. COCA-STEFANIAK, 2020. Changing Grocery Shopping Behaviours Among Chinese Consumers At The Outset Of The COVID-19 Outbreak. Tijdschrift Voor Economische En Sociale Geografie, [online]. [cit. 20th September 2020]. Available from: https://doi.org/10.1111/tesg.12420

[28] LIM, Y., A. OSMAN, S. N. SALAHUDDIN, A. R. ROMLE and S. ABDULLAH, 2016. Factors Influencing Online Shopping Behavior: The Mediating Role of Purchase Intention. Procedia Economics and Finance, 35(1), 401-410. ISSN 22125671.

[29] MAAT, K. and R. KONINGS, 2018. Accessibility or Innovation? Store Shopping Trips versus Online Shopping. Transportation Research Record: Journal of the Transportation Research Board, 2672, 1-10. ISSN 0361-1981.

[30] MANSORI, S., C. B. LIAT and L. H. SHAN, 2012. A Study Of E-Shopping Intention In Malaysia: The Influence Of Generation X \& Y. Australian Journal of Basic and Applied Sciences, 6(8), 28-35. ISSN 1991-8178.

[31] MARTIN-NEUNINGER, R. and M. B. RUBY, 2020. What Does Food Retail Research Tell Us About the Implications of Coronavirus (COVID-19) for Grocery Purchasing Habits? Frontiers in Psychology, 11. ISSN 1664-1078.

[32] MIŠKOLCI, S., 2017. Consumer Preferences Expressed via Shopping in Alternative Food Chains. Acta Universitatis Agriculturae et Silviculturae Mendelianae Brunensis, 65(1), 311-318. ISSN 1211-8516.

[33] MORTIMER, G., S. F. HASAN, L. ANDREWS and J. MARTIN, 2016. Online grocery shopping: the impact of shopping frequency on perceived risk. The international Review of Retail, Distribution and Consumer Research, 26(2), 1-22. ISSN 0959-3969.

[34] MUNSON, J., T. TIROPANIS and M. LOWE, 2017. Online Grocery Shopping: Identifying Change in Consumption Practices. In: Internet Science, Lecture Notes in Computer Science. Proceedings of the 4th International Conference on Internet Science. Greece: Springer, Cham, 192-211.

[35] NESLIN, S. A., D. GREWAL, R. LEGHORN, V. SHANKAR, M. L. TEERLING, J. S. THOMAS and P. C. VERHOEF, 2006. Challenges and Opportunities in Multichannel Management. Journal of Service Research, 9(2), 95-113. ISBN 978-3-319-70284-1. 
[36] NIELSEN, 2020. Online Grocery Shopping [online]. [cit. 22nd September 2020]. Available from: https://www.nielsen.com/us/en/press-releases/2018/fmi-and-nielsenonline-grocery-shopping-is-quickly-approaching-saturation/

[37] PAUZI, S., A. THOO, L. TAN, F. MUHARAM and N. TALIB, 2017. Factors Influencing Consumers Intention for Online Grocery Shopping - A Proposed Framework. IOP Conference Series: Materials Science and Engineering, 215, 1-12. ISSN 1757-8981.

[38] RAHMAN, S., 2015. Consumer Expectation from Online Retailers in Developing Ecommerce Market: An Investigation of Generation $\mathrm{Y}$ in Bangladesh. International Business Research, 8(7), 121-137. ISSN 1913-9004.

[39] ROBINSON, H., F. D. RILEY, R. RETTIE and G. ROLLS-WILLSON, 2007. The role of situational variable in online grocery shopping in the UK. The Marketing Review, 7(1), 89-106. ISSN 1469347X.

[40] SALEEM, M., M. MATEEN KHAN, M. EKHLAQUE AHMED, S. ALI NEHA SHAH and S. RAFIQ SURTI, 2018. Online Grocery Shopping and Consumer Perception: A Case of Karachi Market in Pakistan. Journal of Internet and E-Business Studies, 2018, 113. ISSN 21690391.

[41] SEITZ, C., J. POKRIVČÁK, M. TÓTH and M. PLEVNÝ, 2017. Online grocery retailing in Germany: an explorative analysis. Journal of Business Economics and Management, 18, 1243-1263. ISSN 1611-1699.

[42] STATISTA, 2019. E-commerce worldwide [online] [cit. 24th August 2020]. Dostupné z: https://www.statista.com/topics/871/online-shopping/

[43] STATISTA, 2020a. Online grocery [online]. [cit. 23rd September 2020]. Available from: https://www.statista.com/statistics/730965/online-grocery-sales-value-worldwide/

[44] STATISTA, 2020b. U.S Online grocery orders due to coronavirus 2020 [online]. [cit. 22nd September 2020]. Available from: https://www.statista.com/statistics/1106449/likelihood-online-grocery-due-tocoronavirus-home-usa/

[45] THE NIELSEN COMPANY. Nielsen Global E-Commerce and The New Retail Report, 2015 [online] [cit. 16th August 2020]. Available from: https://www.nielsen.com/content/dam/nielsenglobal/vn/docs/Reports/2015/Nielsen\%20G lobal\%20E-

Commerce\%20and\%20The\%20New\%20Retail\%20Report\%20APRIL\%202015\%20(Dig ital).pdf

[46] VAN DROOGENBROECK, E. and L. VAN HOVE, 2020. Intra-household task allocation in online grocery shopping: Together alone. Journal of Retailing and Consumer Services, 56, 102153. ISSN 0969-6989. 